\title{
A gastrooesophagealis refluxbetegség nyelőcsőszövődményei: következmények vagy védekezőreakciók?
}

\author{
Horváth Örs Péter dr. ${ }^{1}$ - Bognár Laura dr. ${ }^{2}$ \\ Papp András dr. ${ }^{1}$ - Vereczkei András dr. ${ }^{1}$ \\ Pécsi Tudományegyetem, ${ }^{1}$ Klinikai Központ, Sebészeti Klinika, \\ ${ }^{2}$ Sebészeti Oktató és Kutató Intézet, Pécs
}

\author{
A jelen tudományos közleményt a szerzök \\ a Pécsi Tudományegyetem alapitásának 650. évfordulója emlékének szentelik.
}

\begin{abstract}
A gastrooesophagealis refluxbetegség a felnőtt lakosság több mint 10\%-át érinti. A betegek nagy többsége életmódbeli változtatásokkal és hatásos savcsökkentő szerekkel jól kezelhető. Az érintettek körülbelül 10\%-a azonban a kezelés dacára panaszos marad, és náluk súlyos szövődmények fejlődhetnek ki. Különös módon a szövődmények egy része védekező jellegünek tűnik, amivel a beteg panaszai mérséklődhetnek, illetve mintha az állapot súlyosbodásának és további szövődmények kialakulásának megelőzését céloznák. Az egyértelmúen refluxszövődménynek tekinthető Barrett-oesophagusban jelentősen mérséklődhetnek az életminőséget rontó panaszok, mert a Barrett-hám sokkal ellenállóbb a gyomorsav maró hatásával szemben, mint a nyelőcsövet normálisan bélelő laphám. A refluxszövődményként kialakuló motilitászavarok (hipertenzív alsó nyelőcsősphincter, achalasia cardiae és cricopharyngealis achalasia) és strukturális elváltozások (Schatzki-gyưrű, nyelőcsőstrictura, subglotticus tracheastenosis) pedig segítenek megelőzni az aspirációt, amely újabb panaszok megjelenésével járhat, és további súlyos szövődmények kialakulásának a lehetőségét hordozza magában.
\end{abstract}

Orv Hetil. 2017; 158(20): 763-769.

Kulcsszavak: gastrooesophagealis refluxbetegség, Barrett-oesophagus, motilitászavarok, gastrooesophagealis refluxszövődmények, védekezőreakció

\section{Esophageal complications of gastroesophageal reflux disease: consequences or defensive reactions?}

Gastroesophageal reflux disease affects more than $10 \%$ of the adult population. Most patients can be effectively treated with lifestyle changes and adequate acid-reducing therapy. However, about $10 \%$ of the patients remain symptomatic despite treatment and severe complications may develop. Interestingly, some of these complications seem to be a sort of defensive mechanism that may either alleviate the patient's symptoms or prevent developing further complications. In Barrett's esophagus, which can be unambigously considered as a complication of gastroesophageal reflux disease, reflux symptoms ruining the quality of life may significantly improve, since the metaplastic Barrett epithelium is much more resistent to gastric acid, than the normal epithelial lining of the esophagus. Furthermore, the motility disorders (hypertensive lower esophageal sphincter, achalasia, cricopharyngeal achalasia) and structural changes (Schatzki's ring, esophageal stricture, subglottic trachea stenosis), which develop as a complication of reflux may help to prevent aspiration that can cause new complaints and may lead to further complications.

Keywords: gastroesophageal reflux disease, Barrett's esophagus, motility disorders, gastroesophageal reflux complications, defensive reaction

Horváth ÖP, Bognár L, Papp A, Vereczkei A. [Esophageal complications of gastroesophageal reflux disease: consequences or defensive reactions?]. Orv Hetil. 2017; 158(20): 763-769.

(Beérkezett: 2017. március 18.; elfogadva: 2017. április 13.)

Az Orvosi Hetilap alapításának 160. évében, a Szerkesztőség felkérésére készített tanulmány. 


\section{Rövidítések}

GERD = (gastroesophageal reflux disease $)$ gastrooesophagealis refluxbetegség; hLES = (hypertensive lower esophageal sphincter) hipertenzív alsó nyelőcső-záróizom; LES = (lower esophageal sphincter) alsó nyelőcső-záróizom; PPI = (proton pump inhibitor) protonpumpa-inhibitor; UES $=$ (upper esophageal sphincter) felső nyelőcső-záróizom

A refluxbetegség orvosi jelentőségét alapvetően az adja, hogy az életminőséget jelentősen rontó panaszokat okozhat, és nehezen kezelhető, súlyos szövődményekkel járhat. A betegség a felnőtt lakosság legalább 10\%-át érinti, ezért kiemelkedő fontosságú. A GERD 80-90\%-a konzervatív módszerekkel jól kezelhető, a panaszok és szövődmények elkerülhetők. A fennmaradó 10-20\%-ban találkozunk egy úgynevezett progresszív formával, ahol súlyos szövődmények fejlődhetnek ki, és komolyan felmerül a sebészi indikáció kérdése is [1]. A progresszív lefolyású GERD egyik leggyakoribb szövődménye a Barrett-oesophagus kialakulása, amely praecarcinosisnak tekinthető, és ma a leggyorsabb incidencianövekedést mutató daganatnak, a nyelőcső-adenocarcinomának képezi a kiindulási alapját. Ugyanakkor, érdekes módon, a Barrett-oesophagus kialakulása jelentősen mérsékelheti a refluxbetegség sok szenvedést okozó tüneteit, a substernalis égő érzést és az epigastrialis fájdalmat, mert a Barrett-hám sokkal ellenállóbb a gyomorsav maró hatásával szemben, mint a nyelőcsövet normálisan bélelő laphám [2]. A szövődményként kialakuló motilitászavarok (hLES, achalasia cardiae és cricopharyngealis achalasia) és strukturális elváltozások (Schatzki-gyürü, nyelőcsőstrictura, proximális nyelőcsőstrictura, web, subglotticus tracheastenosis) pedig segítenek megelőzni az aspirációt, amely újabb panaszok megjelenésével járhat és további súlyos szövődmények kialakulásának a lehetőségét hordozza magában.

Ezek az elváltozások vajon véletlenszerúen jönnek létre vagy a szervezet alkalmazkodóképességeként védekezőreakcióknak tekinthetők? Vegyük sorba ezeket a folyamatokat az irodalom és saját beteganyagunkból kiválasztott esetek ismertetésével!

$\mathrm{Az}$ aspirációt a szervezet egészséges emberben is változatos védekezőmechanizmusokkal igyekszik megakadályozni. A refluxbetegség egyik gyakori extraoesophagealis szövődménye az aspirációból eredő pulmonológiai és fül-orr-gégészeti komplikációk. A leginkább bizonyítottnak tưnő védekezési forma a reflux következményeként létrejövő aspirációval szemben a hLES kifejlődése. Ebben az esetben az alsó nyelőcsősphincter nyomása a normális háromszorosára emelkedhet, és 45-60 Hgmm-t lehet mérni manometriával. A betegnek sokszor egyaránt lehetnek dysphagiás és refluxos panaszai. Az achalasiától jól elkülöníthető manometriával, mert a nyelőcsőtest perisztaltikája propulzív és a sphincter tud relaxálni. A mi beteganyagunkban 1998 és 2006 között refluxbetegség miatt operált 241 betegből hat esetben észleltünk
hLES-t (2,7\%). A nemzetközileg elismert adelaide-i munkacsoport közel 2000 betegéből 1,6\%-ban talált hasonló motilitási zavart [3]. HLES esetén a betegek közel felében 24 órás $\mathrm{pH}$-metriával kóros reflux mutatható ki, és a fó bizonyíték a reflux szerepére az, hogy Nissen-fundoplicatio után rendeződik a sphincternyomás és normalizálódik a pH-metria, továbbá megszűnnek a beteg nyelési és refluxos panaszai $[3,4]$. A mi hat betegünk átlagos DeMeester-score-ja a mútét előtt $41,7(35,6-81,3)$ volt, majd hat héttel a fundoplicatio után normális értékre, 2,9-re csökkent. Az átlagos alsónyelőcsősphincter-nyomás 50,5 Hgmm-ről $(35,6-81,3)$ több mint a felére csökkent $(24,7 \mathrm{Hgmm})$. Az alsónyelőcsősphincternyomás emelkedését felfoghatjuk védekezőreakciónak. A reflux indukálta hLES kezelése fundoplicatióval paradox, mert a fundoplicatio antirefluxmútétként alkalmazva emeli a LES-nyomást, ebben az esetben azonban a kiváltó okot megszüntetve normalizálja azt. Dell'AcquaCassão igazolta, hogy a hLES-en kívül a reflux okozhat diffúz oesophagusspasmust és diótörő (nutcracker) nyelőcsövet is, és laparoszkópos fundoplicatio után a motilitási zavarok rendeződnek [5].

További védekezési forma egy submucosus, fibroticus gyürünek, a Schatzki-gyürünek a kialakulása, amely nagyon gyakran reflux és szinte mindig hiatushernia mellett fordul elő. A Schatzki-gyưrü kezelésére standard terápiaként használt tágító kezelés önmagában nem biztosít hosszú távú tünetmentességet, a gyưrü legtöbbször újra kialakul, ami újabb és újabb tágító kezelést tesz szükségessé. A tágító kezelés után adott hosszú távú PPI-terápiával azonban a recidíva megelőzhető, ami indirekt bizonyítéknak tekinthető a reflux kiváltó szerepére $[6,7]$. Érdekes, de érthető megfigyelés, hogy a Schatzkigyưrü kialakulása után a refluxos panaszok csökkennek és a dysphagiás panaszok kerülnek előtérbe [8].

Az idiopathiás UES-nyomásfokozódás és a reflux együttes előfordulása jogosan veti fel az összefüggést a két lelet között. Ismert, hogy a szervezetet normális esetben is összetett aerodigesztív reflexek védik az aspirációtól [9]. Több tanulmány szerint a felső sphincter nyomásfokozódása vagy inkoordinált múködése összefüggésbe hozható kóros, magasra terjedő refluxszal és ezáltal egy aspiráció elleni protektív reakcióként is értékelhető $[10,11]$. Az UES múk ödési zavara olyan súlyos lehet, hogy a betegnek komoly dysphagiája léphet fel aspirációval, krónikus köhögéssel.

\section{Esetismertetések}

\section{Elsö beteg}

Egy 43 éves nőbeteg nyaki szakaszra lokalizálható nyelési panaszokkal és éjszakai köhögéssel jelentkezett klinikánkon. Korábbiakban nem túl súlyos refluxos panaszai is voltak. Nyelésvizsgálattal a pharyngooesophagealis átmenetben körülbelül $3 \mathrm{~cm}$-es szakaszon szúkületet találtunk (1. ábra). A szúkület magasságában a nyálkahártya 


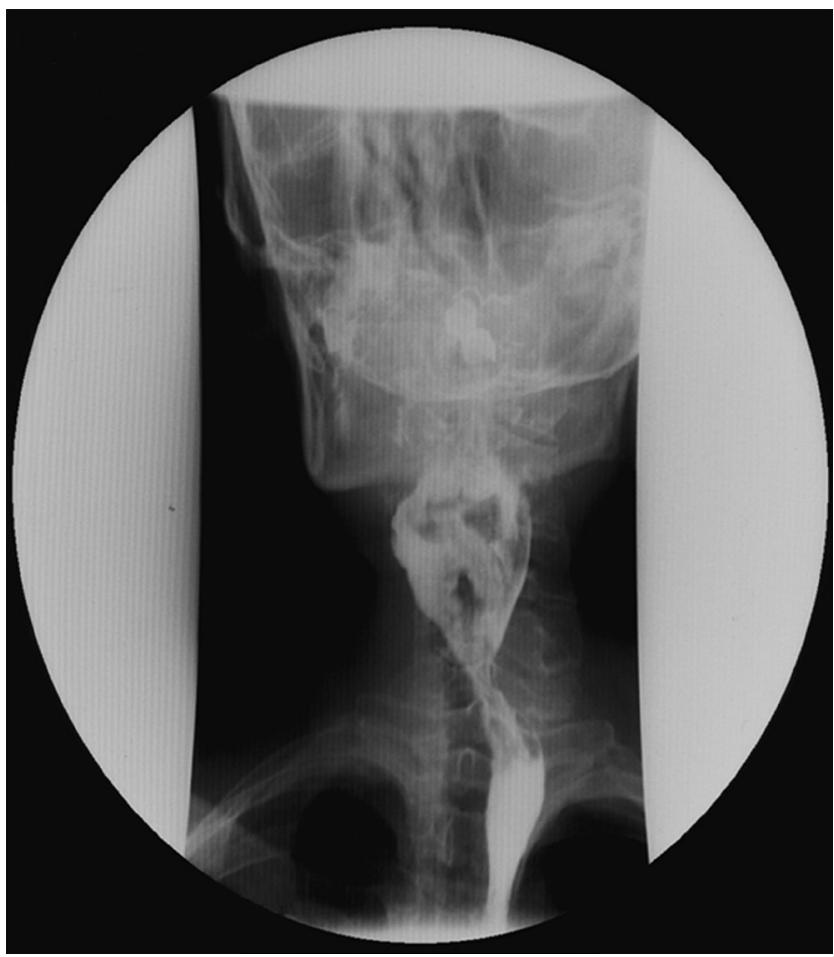

1. ábra

Felső nyelőcsősphincter „szúkülete”, fokozott UES-nyomásfokozódás miatt

épnek tûnt. A CT-vizsgálat mérsékelt szimmetrikus falmegvastagodást mutatott. Daganat lehetősége nem merült fel. A szúkü̈leten az endoszkópot nyomással át lehetett vezetni, és a nyálkahártya ép volt. 24 órás pH-metriával 45,5 DeMeester-score-t mértünk. Ennek alapján felmerült a refluxos eredet és a következményes felső nyelőcsősphincter tónusfokozódása. Egy ballonos tágításra és PPI-kezelésre a beteg panaszai megszüntek.

A Zenker-diverticulum kifejlődése is az aspiráció elleni védekezés káros, indirekt következményeként fogható fel. A diverticulum kialakulásában az UES múködészavara, fokozott sphincternyomás és nyeléskor korai záródás játszik szerepet. A garatban kialakuló fokozott nyomás a garat hátsó falán található gyenge területen (Killian-háromszög) a nyálkahártya kiboltosul, és kezelés nélkül fokozatosan nő. A Zenker-diverticulum és a reflux összefüggését az irodalom egyhangúlag feltételezi [12]. Zenker-diverticulum mellett a hiatushernia 39\%-ban fordul elő, míg a kontrollcsoportban csak 16\%-ban. Ugyanez a munkacsoport 72\%-ban mutatott ki kóros refluxot Zenker-diverticulum mellett. Mi egy esetben észleltünk peptikus stricturát és elörehaladott pharyngooesophagealis diverticulumot együtt.

\section{Második beteg}

A 70 éves férfi betegnek körülbelül 10 éve voltak nyelési panaszai, amelyek odáig fokozódtak, hogy csak folyadékot tudott lenyelni, és emellett jellegzetes regurgitatiós és aspirációra jellemző panaszai is jelentkeztek. A nyelésvizsgálaton $8 \mathrm{~cm}$-es Zenker-diverticulumot találtunk, alatta pedig egy hosszú peptikus stricturát (2. ábra). A peptikus strictura óvatos tágítása után omeprazolterápiát kezdtünk, majd elvégeztük a diverticulum reszekcióját és a myotomiát, majd két hónappal később újabb tágító kezelést végeztünk. A beteg panaszmentessé vált. A két szövődmény mindegyikét refluxos eredetúnek tartottuk. Egyedül jelentkező Zenker-diverticulum esetén a terápiás terv nyaki műtét és PPI-kezelés. Az egyidejűleg fennálló hiatushernia megoldása csak befolyásolhatatlan panaszok esetén jön szóba. A bemutatott esetben előbb a peptikus stricturát kellett kezelni, mert anélkül végzett diverticulumreszekciónál veszélyeztettük volna a nyelőcsőnyálkahártya-varratot a várhatóan fennmaradó - a strictura által fenntartott - fokozott nyelési nyomás miatt.

A Zenker-diverticulum kialakulását elősegítő - refluxszal összefüggő - másik teória szerint a kezdődő nyelőcsőstrictura hosszirányú rövidüléssel is jár, és ez húzóeröt gyakorolva a pharyngooesophagealis átmenetre, gyengítheti a Killian-háromszöget, ami a felső nyelőcsősphincter funkciózavara mellett szerepet játszana a diverticulum kialakulásában [13].

A subglotticus tracheastenosis bár nem nyelöcsőszövődmény, de refluxkövetkezmény, és az aspiráció elleni véde-

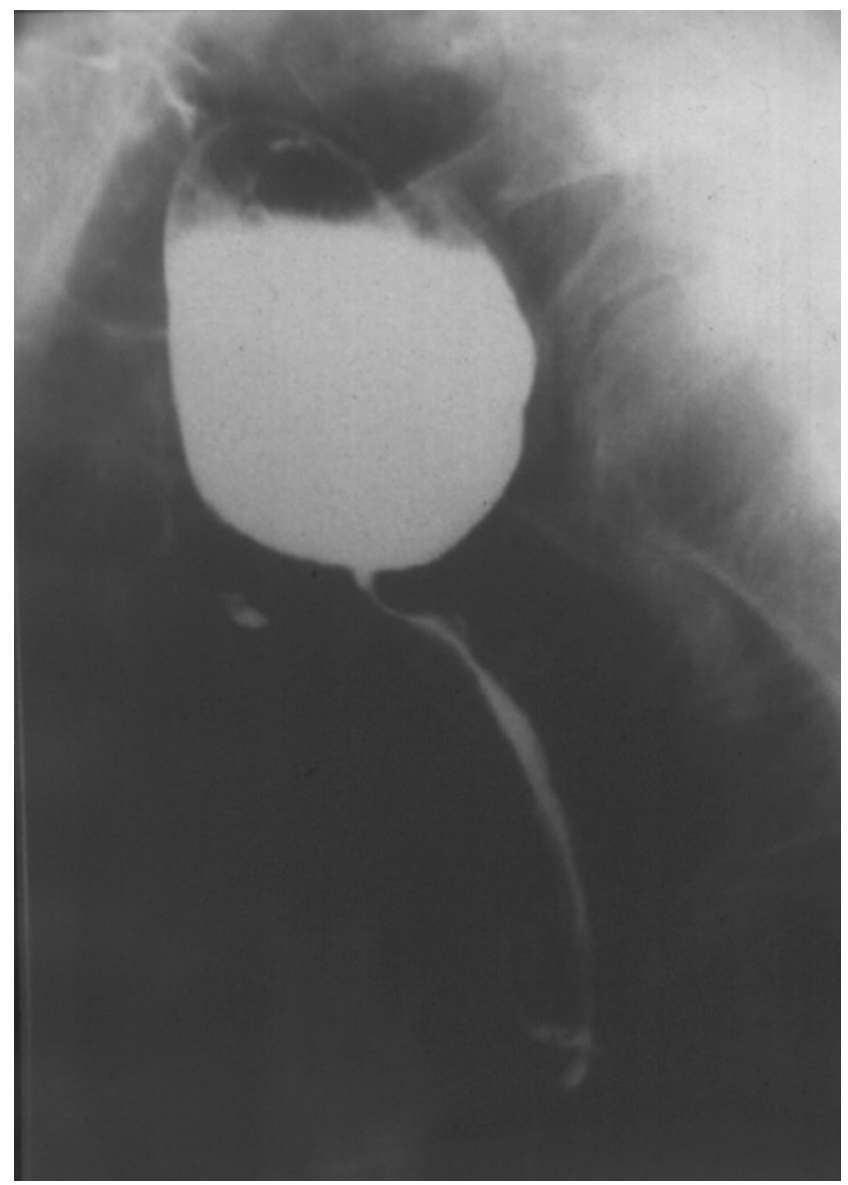

2. ábra 
kezés egyik formájának tartható $[14,15]$. A refluxeredetet igazolni lehet funkcionális vizsgálattal és a tracheából vett minta pepszintartalmából.

\section{Harmadik beteg}

A 70 éves nóbeteg fulladás, stridoros légzés miatt került felvételre. A panaszok oka egy virtuális bronchoszkópiával igazolt subglotticus tracheastenosis volt (3. ábra), a környezetében florid gyulladással. A betegen 40 évvel korábban achalasia miatt Heyrovsky-mútétet (oesophagogastrostomia) végeztek, és azóta folyamatosan volt súlyos refluxos panasza tüdőszövődményekkel. A hatásos savcsökkentő szerek bevezetése előtt a betegnek évekig tracheostomája is volt, majd az antacidterápia elkezdésével a szúküulet foka mérséklődött és a tracheostomát megszüntették. Az oesophagogastrostomát cardiareszekcióval szüntettük meg, és a folytonosságot jejunuminterpozícióval állítottuk helyre. Refluxa megszűnt, és a tracheaszúkületet tágító kezeléssel oldottuk meg.

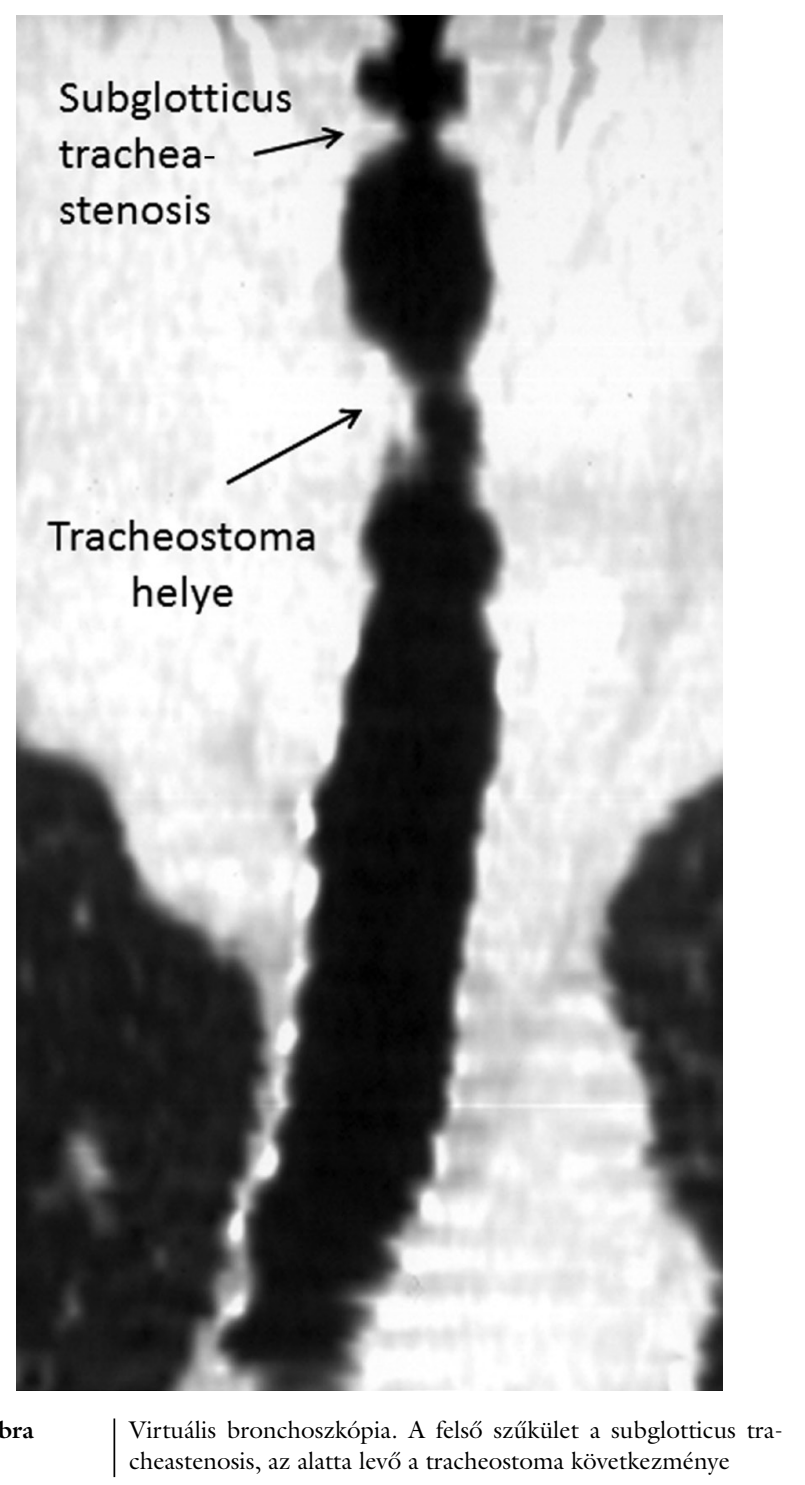

A proximális nyelócsóstrictura, web és a reflux összefüggését Jaspersen 1999-ben publikált cikkében vetette fel, és ez egy újabb védekezési formára hívja fel a figyelmet [16].

\section{Negyedik beteg}

Az 50 éves nóbeteget fokozatosan kialakuló nyelési panaszok miatt vizsgáltuk. Felvételkor csak folyadékot tudott fogyasztani. A nyelésvizsgálaton a nyelőcső felső és középső harmadának határán találtunk egy hártyaszerű szúkületet (4. ábra). A szúkület egy tágító kezeléssel megszünt. A tágító kezelés után fellépő refluxos panaszok vetették fel a refluxos eredetet, mert a kezelés előtt erre utaló panasz vagy jel nem volt. Omeprazolterápia mellett egy évig panasz- és tünetmentes volt, ezt követően kontrollvizsgálatokon nem jelent meg.

A refluxszövődmények elleni védekezés egyik, az irodalomban erősen vitatott formája az achalasia. Ismert dolog, hogy a nyelőcső-motilitási zavarok egymásba, sőt achalasiába is átmehetnek [17]. Az első közlemény, amely felvetette a reflux etiológiai szerepét az achalasia kialakulásában, 1986-ban jelent meg. Ebben öt esetről számoltak be, amikor igazolt refluxbetegséget követően az évek során achalasia alakult ki [18]. Később Robson részletesen dokumentálva ismertetett egy esetet, amikor refluxbetegség diffúz nyelőcsőspasmusba, majd achalasi-

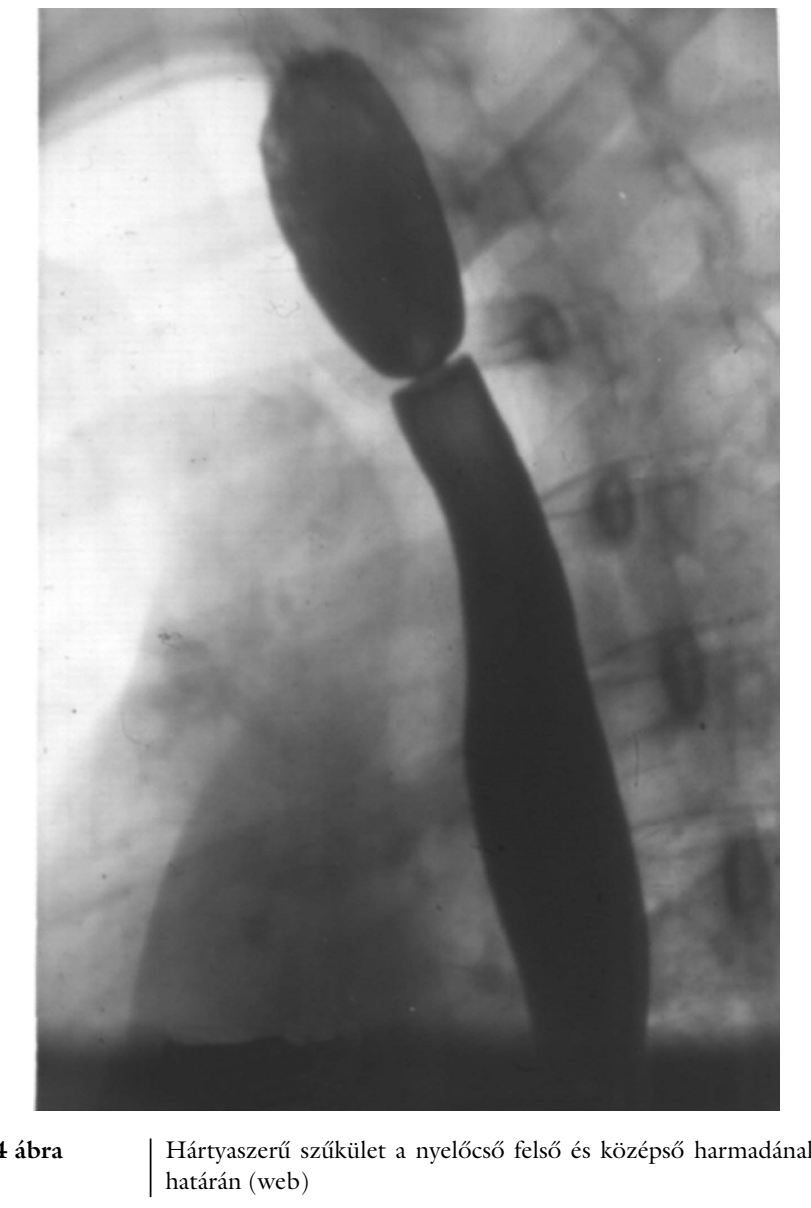


ába progrediált [19]. Azóta több hasonló esetismertetésben írták le az éveken át tartó refluxos panaszok megszűnését, majd dysphagia kialakulását. A panaszok megjelenésének időrendi állandósága arra enged következtetni, hogy a kórképek között esetleg ok-okozati öszszefüggés áll fenn, mégpedig az, hogy a krónikus savas regurgitatióra védekezésképpen a szervezet achalasia kialakulásával fog reagálni. Klinikánkon az elmúlt 15 évben 40 beteget operáltunk achalasia miatt, közülük négy betegnél $(10 \%)$ merült fel a reflux etiológiai szerepe. Bár a reflux és az achalasia az alsó nyelőcsősphincter motilitási zavarainak két ellentétes pólusát képezik, a kezeletlen achalasiás betegek 10-20\%-ánál lehet a nyelőcsőben savas regurgitatiót mérni. Saját betegeinknél végzett 24 órás pH-metriás vizsgálatok hosszabb refluxos epizódokat mutattak ki az éjszaka folyamán, amiból arra lehetett következtetni, hogy a betegeknél átmeneti LES-relaxáció lépett fel, és a károsodott motilitású nyelőcsőből a regurgitált sav nagyon nehezen ürült ki. Ezt a megfigyelést korábban Hirano is leírta [20]. Jogos lenne a feltételezés, hogy ezeknek a savas epizódoknak a hátterében valójában nem is igazi reflux áll, hanem a károsodott perisztaltikájú, dilatált nyelőcsőben retineált táplálék fermentációjából származó laktátakkumuláció. Kutatások bizonyították azonban, hogy ez a Lactobacillusok által okozott fermentáció 3,5-nél alacsonyabb pH-t sosem okoz, míg a mi betegeinknél a nyelöcsőben mért pH 3 alá is csökkent, ami bizonyítja az igazi refluxos eredetet [21]. A reflux achalasiát megelőző fennállását támogatja az a megfigyelés is, hogy több kezeletlen achalasiás betegnél írták le a Barrett-oesophagus, sőt nyelőcső-adenocarcinoma együttes jelenlétét, amelyek köztudottan hosszas refluxbetegséget követően alakulnak ki [22]. Hasonlóképpen, hiatushernia és achalasia együttes fennállásáról is beszámoltak már. Jól ismert tény, hogy a rekeszsérv gyakran jár együtt refluxszal, mert az antirefluxmechanizmus anatómiai része meggyengül, mert megnyúlik a phrenooesophagealis ligamentum, és nincs intraabdominalis nyelőcsőszakasz, tehát paradox az achalasia és a hiatushernia előfordulása $[23,24]$, és ennek megfelelően extrém ritkaságnak számít. Mi egy achalasiás betegnél észleltünk hiatusherniát és pozitív pH-metriát, valamint Barrett-metaplasiát.

\section{Ötödik beteg}

Egy 63 éves nőbeteg öt éve tartó refluxos panaszai hátterében Savary-Miller II-es típusú refluxoesophagitis igazolódott. PPI-terápiát kezdtek, amelynek hatására a következő évi kontrollendoszkópia oesophagitist nem írt le. Az ezt követő évben a betegnél a refluxos panaszok teljesen megszüntek, ellenben dysphagia kezdett megjelenni. Ekkor jelentkezett klinikánkon, és az ekkor elvégzett endoszkópia már dilatált nyelőcsőtestet írt le erozív oesophagitissel, beszúkü̈lt cardiával és kis hiatusherniával. A distalis nyelőcsőből vett biopsziás minták megerősítették az oesophagitist, továbbá Barrett-metaplasiát ír- tak le. Kontrasztanyagos nyelésvizsgálattal károsodott perisztaltikájú dilatált nyelő́csövet találtunk, nem relaxáló alsónyelőcső-sphincterrel (5. ábra). Ez utóbbit a nyelőcső-manometriás vizsgálatok is megerősítették. A 24 órás pH-metriás vizsgálat 64,2 DeMeester-score-t igazolt. A betegnél achalasiát és vele párhuzamosan refluxbetegséget diagnosztizáltunk. A beteget megoperáltuk, hiatusrekonstrukciót végeztünk, valamint Heller-myotomiát 360 fokos fundoplicatióval. A mütét utáni kétéves kontrollvizsgálaton a beteg panaszmentes volt.

Érdekes morfológiai elváltozásokról számolt be Altorjay, aki refluxos betegek alsó nyelőcső-záróizmából vett izombiopsziás mintákat vizsgált, és azt találta, hogy a mintákban a strukturális protein S-100 és a myofibrillaris protein troponin I koncentrációja jelentősen emelkedett, és felvetette, hogy a LES efféle hypertrophiaszerü elváltozásának szerepe lehet a reflux indukálta achalasia kialakulásában [25]. Egy másik közleményében Altorjay ugyanilyen biopsziás mintákban a myentericus plexus gyulladását írta le és feltételezte, hogy ez a patológiai elváltozás különböző funkcionális nyelőcsőbetegségekhez vezethet [26]. Moses és mtsai igazolt refluxos és achalasiás betegek szérumát vizsgálták és azt találták, hogy nagyon hasonló antineuralis antitestek keringenek mindkét betegcsoportban, ami alapján felvetődött, hogy a két betegség patomechanizmusa hasonló autoimmun mechanizmusokon alapszik. A szerzők azonban azt a következtetést vonták le, hogy nem valószínü, hogy ezeknek a hasonló antineuralis antitesteknek funkcionális követ-

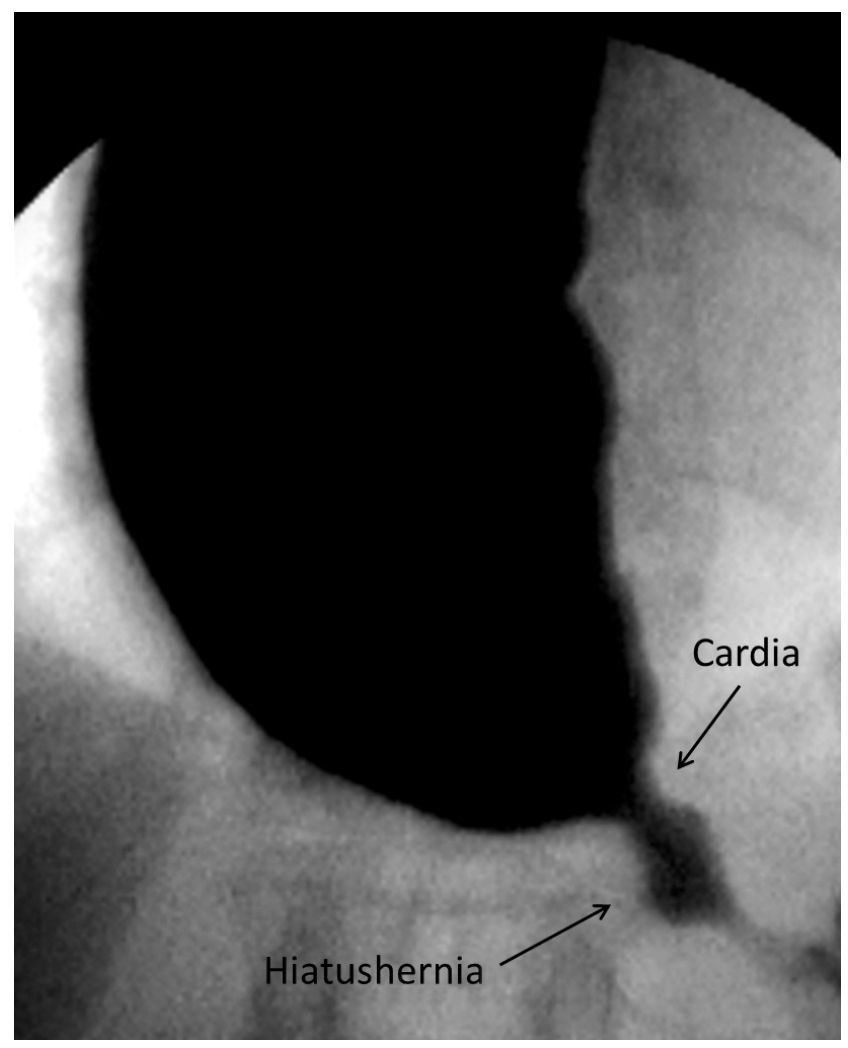

5. ábra | Achalasia és hiatushernia együttes előfordulása 
kezménye lenne, illetve, hogy a betegségek kialakulásában szerepük volna [27].

$\mathrm{Az}$ achalasia, mai tudásunk szerint, nem gyógyítható, az összes kezelési forma a betegség tüneteinek mérséklésére irányul. Enyhébb esetekben átmeneti megoldást jelenthet a pneumatikus ballondilatatio vagy az endoszkópos botulinum toxin injektálása, súlyosabb esetekben mútét indikált. A standard mütét ilyenkor egy parciális fundoplicatióval kiegészített Heller-myotomia, azonban a beavatkozás után közel 10\%-ban posztoperatív reflux alakul ki. Miután ez a szám nagyjából megfelel a reflux talaján kialakult achalasia arányának [20], feltételezhető, hogy a posztoperatív időszakban azoknál a betegeknél lép fel reflux, akiknél az achalasia egyébként is hosszan tartó refluxbetegséget követően alakult ki [28]. Ennek elkerülése érdekében mi azt javasoljuk, hogy ezeknél a betegeknél a Heller-myotomia ne parciális, hanem 360 fokos fundoplicatióval legyen kiegészítve.

A szervezet védekezésének különös formájának tekinthető a Barrett-oesophagus is [29]. Típusos esetben az éveken át tartó súlyos refluxos panaszok fokozatosan megszünnek, amelynek az oka nem kizárólag az, hogy jól kezelik a betegséget, hanem az, hogy saválló metaplasztikus hám borítja a nyelőcsövet. A legelfogadottabb és részben bizonyított elmélet szerint a savas reflux megbontja a laphámsejtek közötti kapcsolódást, és a sejt közötti hézagokon keresztül az őssejtekig lejuthatnak a genetikai elváltozást okozó anyagok, amelyek valószínúleg biliaris eredetűek. Kimutatták, hogy a Barrett-hám kialakulása után a sejtek közötti szoros illeszkedés (tight junction) sokkal kifejezettebb, és csökken a sejtek közötti permeabilitás [30]. Ennek fontos tényezője, hogy szignifikánsan nő a szoros illeszkedés legfontosabb alkotórészének, a claudin-18-nak a mennyisége a sejtek között, és ez nagyban hozzájárul a savas reflux elleni védelemhez. Ez a munkacsoport [29] használta először az "adaptive protection” (alkalmazkodó védelem) kifejezést erre a jelenségre.

DeMeester teóriája szerint a savcsökkentő szerek széles körü alkalmazásának a '70-es évek óta nagy valószínüséggel szerepe van a Barrett-oesophagus és a nyelőcsőadenocarcinoma rendkívül gyors elterjedésében [31]. E teória szerint, ha a kevert refluxos beteget erős savcsökkentőkkel kezelik, akkor a refluxátum pH-ja 4-6 közé emelkedik, és ezen a pH-szinten az epesavak metabolizmusában olyan molekulák keletkeznek, amelyek a progenitor sejtekben genetikai változásokat hoznak létre, így azok ezt követően metaplasztikus hámot termelnek laphám helyett.

Nancarrow és mtsai összehasonlító genomvizsgálatot végeztek Barrett-oesophagus- és egészséges nyelőcsőlaphámból végzett biopsziás anyagban. Az eredmények azt támasztották alá, hogy a Barrett-oesophagusos mintákban megnövekedett glikoproteinszintézist létrehozó génmechanizmus múködik (DPP-4, ATP-2A3, AGR-2), amelynek következtében az új nyálkahártya a gastrooesophagealis reflux okozta irritációnak jól ellenáll [32].
Wang és mtsai 40 génről állapították meg, hogy másképpen expresszálódik Barrett-oesophagusban, mint normális laphámban [33].

Mitre és mtsai érdekes összefüggést találtak két ismert refluxszövődmény, a Barrett-oesophagus és a Schatzkigyürü között, mégpedig azt, hogy a Schatzki-gyuurüs beteganyagban nem fordul elő Barrett-oesophagus [34]. Ez az összefüggés azt támasztja alá, hogy a Schatzkigyưrü kialakulásával a reflux mérséklődik vagy megszünik, és ezzel „megvédi” a nyelőcsövet a további szövődményektől.

\section{Következtetés}

A nyelőcső reakciója tehát rendkívül változatos a közel azonos noxára, a gastrooesophagealis refluxra. Már az sem érthető, hogy miért csupán a betegek felében jön létre oesophagitis, amikor a szubjektív panaszok erőssége és az anamnézis hossza csaknem egyforma lehet. A feltételezett „védekező” reakciók pedig érinthetik külön-külön vagy együtt a két nyelőcsősphinctert, kialakulhat fibroticus szúkület vagy genetikailag megalapozott nyálkahártya-elváltozás. A különbség vajon a betegekben van vagy a refluxátum különbözőségében? Rendkívül érdekes kutatási feladatnak tünik.

A törzsfejlődésben az alkalmazkodás számos formáját ismerjük. Az egyedfejlődésben az alkalmazkodás nehezen vagy egyáltalán nem képzelhető el. A reflux elleni sokrétű védekezés mégis számos nehezen megválaszolható kérdést vet fel. Ennyi koincidencia reálisan nem valószínúsíthető.

Anyagi támogatás: A közlemény megírása, illetve a kapcsolódó kutatómunka anyagi támogatásban nem részesült.

Szerzői munkamegosztás: H. Ö. P.: Kidolgozta a hipotézist, kezelte a cikkben ismertetett betegeket, továbbá a közlemény megszerkesztésében vett részt. B. L.: Hozzájárult a kézirat megszövegezéséhez. P. A.: Az ismertetett betegek kezelésében vett részt. V. A.: A közlemény tartalmi lektorálását végezte. A cikk végleges változatát mindegyik szerző elolvasta és jóváhagyta.

Érdekeltségek: A szerzőknek nincsenek érdekeltségeik.

\section{Irodalom}

[1] Fuchs, K. H., Babic, B., Breithaupt, W., et al.: EAES recommendations for the management of gastroesophageal reflux disease. Surg. Endosc., 2014, 28, 1753-1773.

[2] Sharma, N., Ho, K. Y.: Risk factors for Barrett's oesophagus. Gastrointest. Tumors, 2016, 3, 103-108.

[3] Lamb, P. J., Myers, J. C., Thompson, S. K., et al.: Laparoscopic fundoplication in patients with hypertensive lower esophageal sphincter. J. Gastrointest. Surg., 2009, 13, 61-65.

[4] Varga, G., Kiraly, A., Cseke, L., et al.: Effect of laparoscopic fundoplication on hypertensive lower esophageal sphincter associ- 
ated with gastroesophageal reflux. J. Gastrointest. Surg., 2008, 12, 304-307.

[5] Dell'Acqua-Cassão, B., Mardiros-Herbella, F. A., Farah, J. F., et al.: Outcomes of laparoscopic Nissen fundoplication in patients with manometric patterns of esophageal motility disorders. Am. Surg., 2013, 79, 361-365.

[6] Novak, S. H., Shortsleeve, M. J., Kantrowitz, P. A.: Effective treatment of symptomatic lower esophageal (Schatzki) rings with acid suppression therapy: Confirmed on barium esophagography. AJR Am. J. Roentgenol., 2015, 205, 1182-1187.

[7] Wills, J. C., Hilden, K., Disario, J. A., et al.: A randomized, prospective trial of electrosurgical incision followed by rabeprazole versus bougie dilatation followed by rabeprazole of symptomatic esophageal (Schatzki's) rings. Gastrointest. Endosc., 2008, 67, 808-810.

[8] Szendrényi, V., Oláh, T., Horváth, Ö. P.: Schatzki's ring; a rare complication of gastroesophageal reflux. [A Schatzki-gyúrú, a gastroesophagealis reflux ritka szövődménye.] Magy. Seb., 1991, 44, 183-188. [Hungarian]

[9] Dua, K., Surapaneni, S. N., Kuribayashi, S., et al.: Protective role of aerodigestive reflexes against aspiration: study on subject with impaired and preserved reflexes. Gastroenterology, 2011, 140, 1927-1933.

[10] Babaei, A., Venu, M., Naini, S. R., et al.: Impaired upper esophageal sphincter reflexes in patients with supraesophageal reflux disease. Gastroenterology, 2015, 149, 1381-1391.

[11] Vardar, R., Sweis, R., Anggiansah, A., et al.: Upper esophageal sphincter and esophageal motility in patients with chronic cough and reflux: assessment by high-resolution manometry. Dis. Esophagus., 2013, 26, 219-225.

[12] Morales-Divo, C., Jecker, P., Lippert, B., et al.: Extraesophageal reflux in patients suffering from Zenker's diverticulum]. HNO, $2007,55(7), 546-550$

[13] Sasaki, C. T., Ross, D. A., Hundal, J.: Association between Zenker diverticulum and gastroesophageal reflux disease: development of a working hypothesis. Am. J. Med., 2003, 115(3 Suppl. 1), 169S-171S.

[14] Blumin, J. H., Johnston, N.: Evidence of extraesophageal reflux in idiopathic subglottic stenosis. Laryngoscope, 2011, 121, 12661273

[15] Poetker, D. M., Ettema, S. L., Blumin, J. H., et al.: Association of airway abnormalities and risk factors in 37 subglottic stenosis patients. Otolaryngol. Head Neck Surg., 2006, 135, 434-437.

[16] Jaspersen, D., Diehl, K. L., Geyer, P., et al.: Benign proximal esophageal stenosis - mostly a complication of gastroesophageal reflux disease. Dtsch. Med. Wochenschr., 1999, 124, 205-208.

[17] Patti, M. G., Herbella, F. A.: Achalasia and other esophageal motility disorders. J. Gastrointest. Surg., 2011, 15, 703-707.

[18] Smart, H. L., Mayberry, J. F., Atkinson, M.: Achalasia following gastro-oesophageal reflux. J. R. Soc. Med., 1986, 79, 71-73.

[19] Robson, K., Rosenberg, S., Lembo, T.: GERD progressing to diffuse esophageal spasm and then to achalasia. Dig. Dis. Sci., $2000,45,110-113$
[20] Hirano, I., Tatum, R. P., Shi, G., et al.: Manometric heterogene ity in patients with idiopathic achalasia. Gastroenterology, 2001, 120, 789-798.

[21] Streets, C. G., DeMeester, T. R.: Ambulatory 24-hour esophageal $\mathrm{pH}$ monitoring: why, when, and what to do. J. Clin. Gastroenterol., 2003, 37, 14-22.

[22] Guo, J. P., Gilman, P. B., Thomas, R. M., et al.: Barrett's esophagus and achalasia. Fisher J. Clin. Gastroenterol., 2002, 34, 439443.

[23] Kotidis, K. N., Rogers, M. L., Knowles, K. R., et al.: Coexisting achalasia and paraoesophageal hiatal hernia. Eur. J. Cardiothorac. Surg., 2002, 21, 130-132.

[24] Khan, A. A., Shah, S. W., Khan, M. A., et al.: Hiatal hernia in achalasia. J. Pak. Med. Assoc., 1998, 48, 196-197.

[25] Altorjay, A., Juhasz, A., Kellner, V., et al.: Metabolic changes in the lower esophageal sphincter influencing the result of anti-reflux surgical interventions in chronic gastroesophageal reflux disease. World J. Gastroenterol., 2005, 11, 1623-1628.

[26] Altorjay, A., Szilagyi, A., Arato, G., et al.: Morphological changes in the lower esophageal sphincter influencing the result of antireflux surgical interventions in chronic gastroesophageal reflux disease. Hepatogastroenterology, 2006, 53, 342-347.

[27] Moses, P. L., Ellis, L. M., Anees, M. R., et al.: Antineuronal antibodies in idiopathic achalasia and gastro-oesophageal reflux disease. Gut, 2003, 52, 629-636.

[28] Horvath, O. P., Kalmar, K., Varga, G.: Reflux after Heller's myotomy for achalasia. Ann. Surg., 2007, 245, 502-503.

[29] Jovov, B., Van Itallie, C. M., Shabeen, N. J., et al.: Claudin-18: a dominant tight junction protein in Barrett's esophagus and likely contributor to its acid resistance. Am. J. Physiol. Gastrointest. Liver Physiol., 2007, 293, Gl106-G1113.

[30] Gyorffy, H., Holczbauer, A., Nagy, P., et al.: Claudin expression in Barrett's esophagus and adenocarcinoma. Virchows Arch., 2005, 447, 961-968.

[31] DeMeester, T. R., Peters, J. H., Bremner, C. G., et al.: Biology of gastroesophageal reflux disease: pathophysiology relating to medical and surgical treatment. Annu. Rev. Med., 1999, 50, 469-506.

[32] Nancarrow, D. J., Clouston, A. D., Smithers, B. M., et al.: Whole genome expression array profiling highlights differences in $\mathrm{mu}^{-}$ cosal defense genes in Barrett's esophagus and esophageal adenocarcinoma. PLoS ONE, 2011, 6(7), e22513.

[33] Wang, J., Qiu, R., Ma, Y., et al.: Differential gene expression in normal and Barrett's esophagus. J. Gastroenterol., 2009, 44, 897-911

[34] Mitre, M. C., Katzka, D. A., Brensinger, C. M., et al.: Schatzki ring and Barrett's esophagus: do they occur together? Dig. Dis. Sci., 2004, 49, 770-773

(Horváth Örs Péter dr., Pécs, Ifjúság útja 13., 7624 e-mail: horvath.ors.peter@pte.hu)

Az Orvosi Hetilap egyes számai megvásárolhatók a Mediprint Orvosi Könyvesboltban. Cím: Budapest V., Múzeum krt. 17. - Telefon: 317-4948 